International Journal of Health Sciences
Available online at www.sciencescholar.us
Vol.5 No.3, December 2021, pages: 441-448
e-ISSN: 2550-696X, p-ISSN: 2550-6978
https://doi.org/10.53730/ijhs.55n3.1802

\title{
Effect of Self-Hypnosis Therapy with Positive Self-Talk on Stress Levels of COVID-19 Mutual Cooperation Task Force
}

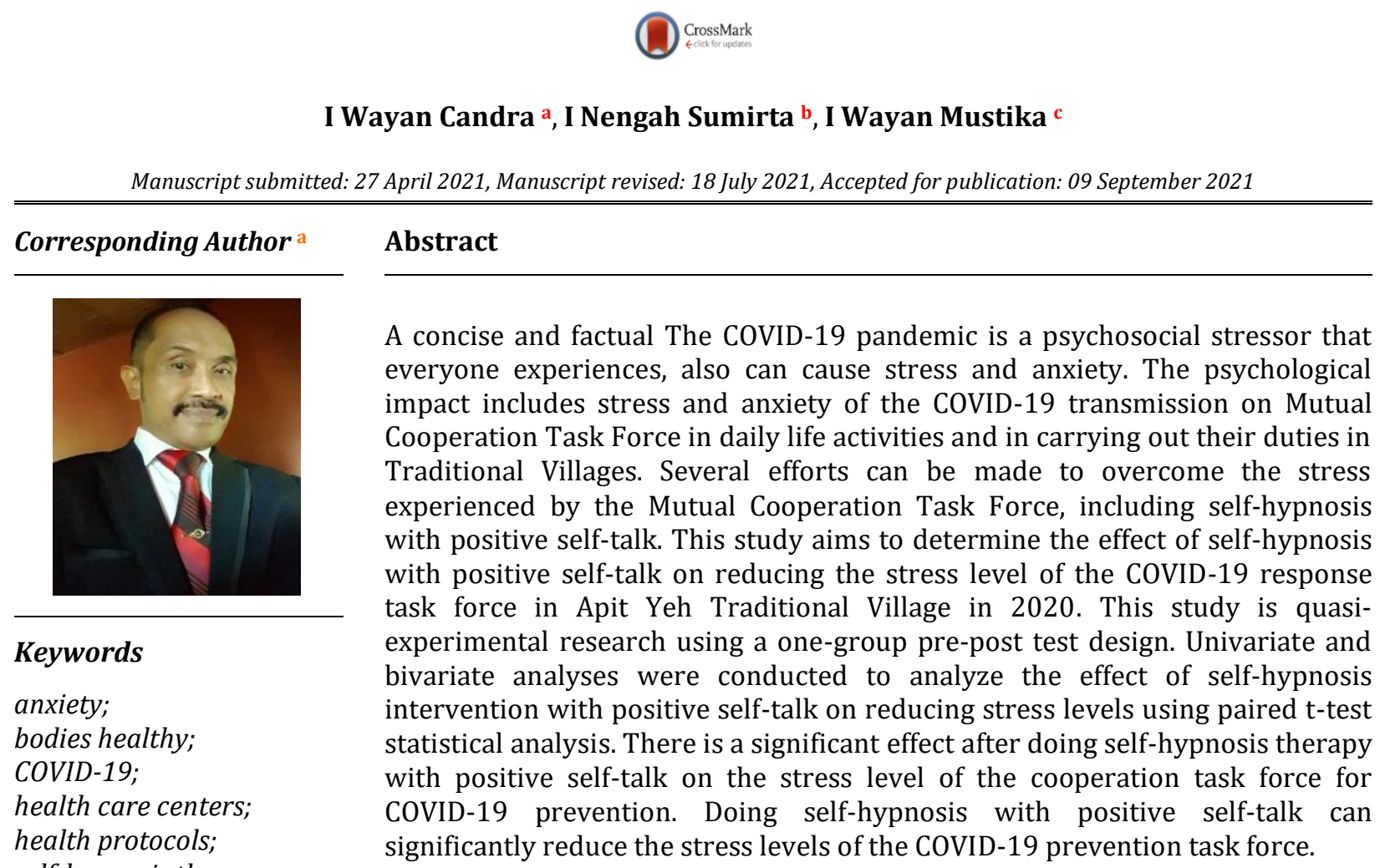

self-hypnosis therapy;

stress levels;

International Journal of Health Sciences (C) 2021.

This is an open access article under the CC BY-NC-ND license (https://creativecommons.org/licenses/by-nc-nd/4.0/).

\footnotetext{
Contents

a Poltekkes Kemenkes Denpasar, Denpasar, Indonesia

b Poltekkes Kemenkes Denpasar, Denpasar, Indonesia

c Poltekkes Kemenkes Denpasar, Denpasar, Indonesia
}

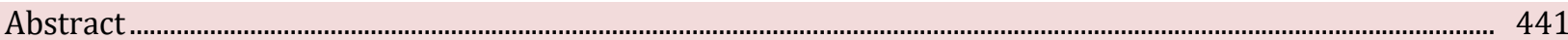

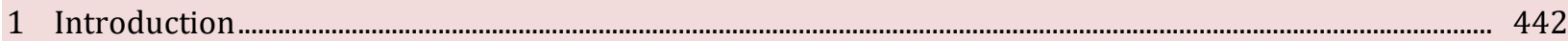

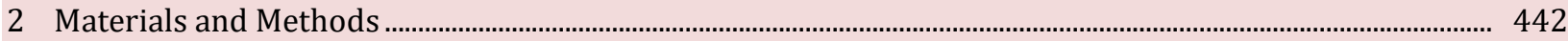

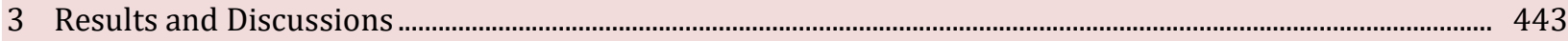

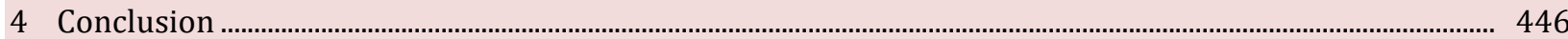

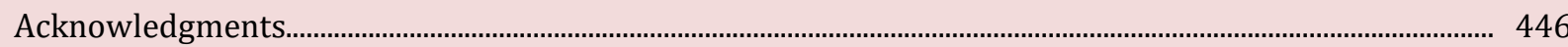

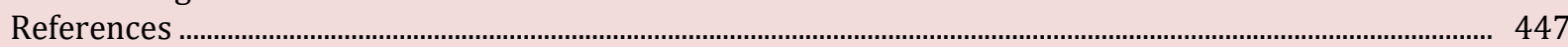




\section{Introduction}

Coronavirus Disease 2019 (COVID-19) is an infectious respiratory disease caused by Severe Acute Respiratory Syndrome Coronavirus 2 (SARS-CoV-2) (WHO, 2020). The most common signs and symptoms of COVID-19 infection may include symptoms of acute respiratory distress such as fever, cough, and shortness of breath. The average incubation period of COVID-19 is 5-6 days and can be as long as 14 days (Ortega-García et al., 2020; Maltezou et al., 2013). In severe cases, COVID-19 infection can cause pneumonia, acute respiratory syndrome, kidney failure, and even death (Kemenkes RI, 2020).

Many efforts were made to prevent the transmission of COVID-19, one of which was the establishment of a Mutual Cooperation Task Force in each Bali's desa adat (customary or traditional village). A total of 1493 Mutual Cooperation Task Forces spread throughout Bali. One of them is the Mutual Cooperation Task Force in the Apit Yeh Traditional Village, Manggis Subdistrict, Karangasem Regency, which is responsible for socializing, educating, preventing, and monitoring the transmission of COVID-19 in the area of Apit Yeh Traditional Village. The COVID-19 pandemic has had a broad impact on people's lives in terms of economic, socio-cultural, and psychological aspects (DPMA Provinsi Bali, 2020). The COVID-19 pandemic is a psychosocial stressor that everyone experiences and causes stress and anxiety (Keliat et al., 2020). The psychological impact includes stress and anxiety of the COVID-19 transmission on Mutual Cooperation Task Force in daily life activities and in carrying out their duties in Traditional Villages (LaMontagne et al., 2001). The emergence of stress and anxiety can be caused by information about COVID-19, separation from family members, not being able to meet family in person, or the responsibilities of taking care of patients with COVID-19 (Keliat et al., 2020). The activity of the endocrine system increases when people are stressed, especially through the activation of the Hypothalamic-Pituitary-adrenal-cortical-axis. Although many different types of neurotransmitters originate in the nervous system, considerable attention has been focused on neuromodulators of the endocrine system or neuropeptides. These hormones affect the nervous system secreted by the glands directly into the bloodstream (Durand \& Barlow, 2006; Mahardika et al., 2021).

Chronic stress causes a prolonged stress response and tends to persist over an extended period, increasing disease occurrence. Davis et al. (2017), found that a person with prolonged stress showed hyperactivity in certain body systems, such as musculoskeletal, cardiovascular, and digestive. Stress is also known to be associated with headaches, muscle tension, arthritis, and fatigue. The occurrence of fatigue can weaken the motivation of the task force to carry out their duties.

Several efforts can be made to overcome the stress experienced by the Mutual Cooperation Task Force, including self-hypnosis with positive self-talk. Positive self-talk includes self-concept, promoting self-efficacy, maintaining self-optimism, building hope, and making oneself happy and joyful (Keliat et al., 2020; Kistan et al., 2020). This method can be one of the most powerful options for relieving stress and stress associated with illness, the easiest and fastest relaxation method (Davis et al., 2017). Hidayat (2019), found that practicing relaxation techniques has the benefits of lowering your heart rate, blood pressure, and breathing rate, reducing the stress hormone, muscle tension, fatigue, and increasing self-confidence. Relaxation can help the vital systems in the bodywork optimally, which can overcome danger to a person's body (Jansson-Fröjmark \& Lindblom, 2008). Based on the problems that have been mentioned above, the researcher is interested in conducting research that aims to determine the effect of self-hypnosis with positive self-talk on reducing the stress level of the COVID-19 response task force in Apit Yeh Traditional Village in 2020.

\section{Materials and Methods}

This study is quasi-experimental research using a one-group pre-post test design. In this study, the researcher observes/measures the research subject group before conducting the intervention. After the intervention was completed, the researcher repeated the first step by observing/measuring the research subject group.

This study was conducted in Apit Yeh Traditional Village, Manggis Subdistrict, Karangasem Regency, Bali Province. The study was conducted from October until November 2020. The population of this study was all 
Mutual Cooperation Task Force for COVID-19 prevention in the Apit Yeh traditional village with a total of 30 people. The sampling technique uses purposive sampling. The research instrument uses standard operating procedures for self-hypnosis with positive self-talk and a stress scale. The data collection techniques and treatment by properly implementing health protocols to prevent transmission of COVID-19 (Kohen \& Zajac, 2007; Spinhoven et al., 1992).

Data analysis uses a computer software program. Univariate analysis was conducted to describe the characteristics of the research subjects. Bivariate analysis was conducted to analyze the effect of self-hypnosis intervention with positive self-talk on reducing stress levels using paired t-test statistical analysis (Hussin et al., 2021). The value is considered statistically significant if $p<0,05$.

\section{Results and Discussions}

Based on the characteristics of research subjects, the majority age group are late adults (36-45 years) by $33,3 \%$. The gender group was mostly male with $93,3 \%$. The highest level of education is secondary education (16 people) with $53.3 \%$. The occupation mostly is farmers with $36,7 \%$. Before receiving treatment, the stress level of research subjects (17 people) mostly experienced moderate stress by $56,7 \%$. After an intervention, there was a change in stress level, where most of the research subjects (19 people) experienced mild stress by $63,3 \%$.

Based on table 4 above, the mean value $=4.90000, t=3,435$, and $p=0.002, p<0.010$. The research hypothesis was accepted. There is a significant effect of self-hypnosis with positive self-talk on the stress level of the cooperation task force for COVID-19 prevention that self-hypnosis with positive self-talk can significantly reduce the stress level of the COVID-19 prevention task force.

Table 1

The characteristics of research subjects of the cooperation task force for COVID-19 prevention in 2021

\begin{tabular}{lll}
\hline \multicolumn{1}{c}{ Characteristics } & $\mathrm{f}$ & $\%$ \\
\hline Age (years) & & \\
Late Adolescence (17-25) & 3 & 10.0 \\
Early Adult (26-35) & 5 & 16.7 \\
Late Adults (36-45) & 10 & 33.3 \\
Early Elderly (46-55) & 8 & 26.7 \\
Elderly ( $\geq 56$ ) & 4 & 13.3 \\
Sex & & \\
Man & 28 & 93.3 \\
Woman & 2 & 6.7 \\
Education & & \\
Basic level & 8 & 26.7 \\
Intermediate Level & 16 & 53.3 \\
High level & 6 & 20.0 \\
Work & & \\
Farmer & 11 & 36.7 \\
Private sector employee & 10 & 33.3 \\
Entrepreneur & 5 & 16.7 \\
Government employee & 4 & 13.3 \\
\hline
\end{tabular}

Candra, I. W., Sumirta, I. N., \& Mustika, I. W. (2021). Effect of self-hypnosis therapy with positive self-talk on stress levels of COVID-19 mutual cooperation task force. International Journal of Health Sciences, 5(3), 441-448. https://doi.org/10.53730/ijhs.v5n3.1802 
Table 2

The stress level of the cooperation task force for COVID-19 prevention based on the characteristics of the research subjects

\begin{tabular}{|c|c|c|c|c|c|c|c|c|}
\hline \multirow{2}{*}{ Characteristics } & \multicolumn{6}{|c|}{ Stress level } & \multicolumn{2}{|c|}{ Total } \\
\hline & Mild & $\%$ & Moderate & $\%$ & Severe & $\%$ & $\mathrm{~N}$ & $\%$ \\
\hline \multicolumn{9}{|l|}{ Age } \\
\hline Late Adolescence & 1 & 3.3 & 2 & 6.7 & 0 & 0 & 3 & 12.0 \\
\hline Early Adult & 3 & 10.0 & 2 & 6.7 & 0 & 0 & 5 & 16.7 \\
\hline Late Adults & 4 & 13.3 & 5 & 16.7 & 1 & 3.3 & 10 & 33.3 \\
\hline Early Elderly & 1 & 3.3 & 7 & 23.3 & 0 & 0 & 8 & 26.6 \\
\hline Elderly & 3 & 10.0 & 1 & 3.3 & 0 & 0 & 4 & 4.3 \\
\hline \multicolumn{9}{|l|}{ Sex } \\
\hline Man & 18 & 60.0 & 10 & 33.3 & 0 & 0 & 28 & 93.3 \\
\hline Woman & 1 & 3.3 & 1 & 3.3 & 0 & 0 & 2 & 6.6 \\
\hline \multicolumn{9}{|l|}{ Education } \\
\hline Basic level & 4 & 13.3 & 3 & 10.0 & 0 & 0 & 7 & 23.3 \\
\hline Intermediate Level & 4 & 13.3 & 12 & 40.0 & 1 & 3.3 & 17 & 56.6 \\
\hline High level & 4 & 13.3 & 2 & 6.6 & 0 & 0 & 6 & 19.9 \\
\hline Work & 3 & 10.0 & 7 & 23.3 & 1 & 3.3 & 11 & 36.6 \\
\hline $\begin{array}{l}\text { Private sector } \\
\text { employee }\end{array}$ & 4 & 13.3 & 7 & 23.3 & 0 & 0 & 9 & 36.6 \\
\hline Entrepreneur & 3 & 10.0 & 1 & 3.3 & 0 & 0 & 4 & 13.3 \\
\hline $\begin{array}{l}\text { Government } \\
\text { employees }\end{array}$ & 2 & 6.7 & 2 & 6.7 & 0 & 0 & 4 & 13.4 \\
\hline
\end{tabular}

Table 3

The stress level of research subjects before and after self-hypnosis treatment with positive self-talk

\begin{tabular}{lcccc}
\hline \multirow{2}{*}{ Level of stress } & \multicolumn{2}{c}{ Before intervention } & \multicolumn{2}{c}{ After intervention } \\
\cline { 2 - 5 } & $\mathrm{N}$ & $\%$ & $\mathrm{~N}$ & $\%$ \\
\hline Mild & 12 & 40.0 & 19 & 63.33 \\
Moderate & 17 & 56.7 & 11 & 36.67 \\
Severe & 1 & 3.3 & 0 & 0 \\
\hline
\end{tabular}

Table 4

The effect of self-hypnosis with positive self-talk on stress levels of the cooperation task force for COVID-19 prevention

\begin{tabular}{|c|c|c|c|c|c|c|c|c|}
\hline & \multicolumn{5}{|c|}{ Paired Differences } & \multirow{3}{*}{$\mathrm{t}$} & \multirow{3}{*}{$\mathrm{df}$} & \multirow{3}{*}{ Sig. } \\
\hline & \multirow[t]{2}{*}{ Mean } & \multirow{2}{*}{$\begin{array}{c}\text { Std } \\
\text { Deviation }\end{array}$} & \multirow[t]{2}{*}{$\begin{array}{l}\text { Average } \\
\text { Std Error }\end{array}$} & \multicolumn{2}{|c|}{$\begin{array}{l}\text { 95\% Confidence Interval of } \\
\text { the Difference }\end{array}$} & & & \\
\hline & & & & Lower & Upper & & & \\
\hline Pair 1 & & & & & & & & \\
\hline $\begin{array}{l}\text { PRETEST- } \\
\text { POSTEST }\end{array}$ & 4.90000 & 7.81400 & 1.42663 & 1.98220 & 7.81780 & 3.435 & 29 & .002 \\
\hline
\end{tabular}


The stress level of the cooperation task force for COVID-19 prevention before self-hypnosis treatment with positive self-talk

The results on the research subjects of the cooperation task force for COVID-19 prevention before being given self-hypnosis therapy with positive talk found that 12 people had mild stress, 17 people had moderate stress, and one person had severe stress. Most subjects experienced moderate stress, with a total of 17 people $(56,7 \%)$. Keliat (2020), found that COVID-19 was a major stressor for the community, including the cooperation task force. All news/information about COVID-19 that is heard, seen, and experienced will make the brain release a stress hormone, i.e., cortisol, which affects various body organs that can cause psychosomatic reactions. Chronic stress causes a prolonged stress response and tends to persist, which can increase the occurrence of disease.

The stress level of the cooperation task force for COVID-19 prevention after self-hypnosis treatment with positive self-talk

The results on the research subjects of the cooperation task force for COVID-19 prevention after being given self-hypnosis therapy with positive talk found that 19 people had mild stress and 11 people had moderate stress. Most subjects experienced moderate stress, totaling 19 people $(63,3 \%)$. There was a decrease in stress scores and stress classification (Attamimi et al., 2020; Widana et al., 2021). Before treatment, one person had severe stress, and after treatment, there was none. There was a change in the classification of mild stress from 12 people $(40,0 \%)$ to 19 people (63.3\%), moderate stress from 17 people (56,7\%) to 11 people (36,7\%). Inabah (2020), found that self-hypnosis enters the subconscious into alpha waves to relax oneself, which causes the vital system to work optimally. The parasympathetic nerves control tension that makes the body relax and stimulate the production of beta-endorphins in the brain, making them happy. Keliat (2020), found self-hypnosis with positive talk, including self-concept, promoting self-efficacy, maintaining self-optimism, building hope, and making yourself happy and joyful. Such situations can make a person relax.

The effect of self-hypnosis with positive self-talk on the stress levels of the cooperation task force for COVID-19 prevention

The results showed the mean value was $4.90000, t=3.435$, and $p=0.002, p<0.010$. There is a significant effect of self-hypnosis with positive self-talk that can reduce the stress levels of the cooperation task force for COVID-19 prevention. The results of similar research have not been found in scientific journals considering that COVID-19 has only occurred less than a year. The research related to COVID-19 is being actively carried out. A similar study with different research subjects conducted by Sari \& Murtini (2015), using relaxation techniques to reduce stress levels in patients with hypertension found a significant decrease in stress scores for the five samples studied. Research conducted by Hanum et al. (2016), using 63 research samples found a significant difference between the calculation results of the total pre-test and post-test scores $(t=3,260$, $\mathrm{p}=0,002)$. Haruyama (2014), found that people who get used to self-hypnosis with positive self-talk and positive thinking strongly resist disease, while those who always have negative views will quickly get sick. Substances whose formation in the body depends on this mindset are hormones. Noradrenaline is produced in the brain when people are stressed and anxious. If people are afraid, their adrenaline will rise. They constantly suffer from severe stress, easily get sick, speed up aging, and increase the risk of early death due to noradrenaline poisoning. On the other hand, if people face something positively by smiling and relaxed, they will produce beneficial hormones, activating brain cells and making their bodies healthy (Saltonstall, 1993; Joling et al., 2019). Murakami (2017), asserted that it is necessary to realize the importance of using selfhypnosis with positive self-talk in times of difficulty and suffering because that's when positive thinking and positive self-talk are needed.

It's important to always remind yourself that every situation in life has two sides: good and bad. Everything depends on our interpretation. For example, when people get sick, it's easy to notice the negative side of the disease that prevents people from working and causes financial stress. At the same time, the disease also has a positive impact, for example, being able to appreciate great people in life or think about ideas hampered by a hectic work schedule. Perhaps people have heard of an experience of how a severe

Candra, I. W., Sumirta, I. N., \& Mustika, I. W. (2021). Effect of self-hypnosis therapy with positive self-talk on stress levels of COVID-19 mutual cooperation task force. International Journal of Health Sciences, 5(3), 441-448. https://doi.org/10.53730/ijhs.v5n3.1802 
disease or serious illness has changed a person's life positively. The trick is to look at it from a broader perspective and believe that being sick will help develop constructively.

The research results imply that self-hypnosis with positive self-talk can be used to reduce stress levels for everyone in the community and various health care centers (McIntyre et al., 2020; Bowman et al., 2020). Selfhypnosis with positive self-talk can improve the ability of thoughts and actions to overcome the problems at hand. The ability of self-hypnosis with positive self-talk to overcome existing problems that arise comes from high self-confidence within yourself (Mustika et al., 2021). With high self-confidence, optimism, radiant facial expressions, the mind will focus on problems and solutions to overcome them. Steady body movements, strong courage, slow and deep breathing will give positive suggestions to yourself. Using feelings that are strongly tied to self-image always feels strong in the subconscious mind. Hence, it becomes a belief. More relaxed breathing makes it possible for all the potential to be realized to overcome the problems at hand (Widjaja, 2021). To achieve such abilities, people need to train themselves continuously in self-hypnosis with positive self-talk when facing difficulties, especially when encountering problems or unwanted events and not finding any positive things from the circumstances they face.

Hill \& Ritt (2014), suggests that a positive mental attitude and behavior can build hope and overcome despair and lack of courage. By having and developing positive mental attitudes and behaviors, people will always have a good, healthy, and productive state of mind when reacting with others and choosing actions. People will feel happy and have their air, light, and feelings that make them appreciate themselves and feel worthy. They can attract positive things and circumstances and reject negative things. The influence of a positive mental attitude and positive behavior will occur automatically, but achieving it cannot be done automatically. A positive mental attitude requires a continuous process, and thereby people can practice it without feeling conscious about it, just like when buttoning a shirt or tying shoelaces. A positive mental attitude and positive behavior can be as natural as breathing. People are all ruled by positive or negative habits depending on the choice. They can choose not to let the mind be ruled by the suggestions of negative thoughts and negative behavior. They can make a conscious decision to replace negative thoughts and ideas and use them for positive things. A positive mental attitude and positive behavior will attract positive things like a magnet attracting metal and attracting people. Self-improvement becomes a shield from doubt and despair when misfortunes enter peoples' lives and visit them.

The ability to do self-hypnosis with positive self-talk is closely related to the use of the human right brain. The use of the dominant right brain allows individuals to more quickly train themselves to do self-hypnosis with positive self-talk because the dominance of the right brain is receptive, creative-imaginative. Left-braindominant individuals handle everything and do routine daily tasks. Therefore, it can be not easy to train themselves to do self-hypnosis with positive self-talk.

\section{Conclusion}

There is a significant effect after doing self-hypnosis therapy with positive self-talk on the stress level of the cooperation task force for COVID-19 prevention. Doing self-hypnosis with positive self-talk can significantly reduce the stress levels of the COVID-19 prevention task force.

Acknowledgments

We are grateful to two anonymous reviewers for their valuable comments on the earlier version of this paper. 


\section{References}

Attamimi, H. R. ., Lestari, Y. ., Situmorang, B. . H. L. ., Antari, G. Y. ., \& Nugrawati, N. . (2020). Application of habituation method in germas interventionsin: the pandemic time COVID-19. International Journal of Health \& Medical Sciences, 3(1), 98-104.

Bowman, B. A., Back, A. L., Esch, A. E., \& Marshall, N. (2020). Crisis symptom management and patient communication protocols are important tools for all clinicians responding to COVID-19. Journal of pain and symptom management, 60(2), e98-e100. https://doi.org/10.1016/j.jpainsymman.2020.03.028

Davis, M. T., Holmes, S. E., Pietrzak, R. H., \& Esterlis, I. (2017). Neurobiology of chronic stress-related psychiatric disorders: evidence from molecular imaging studies. Chronic Stress, 1, 2470547017710916.

Durand, V. M., \& Barlow, D. H. (2006). Intisari psikologi abnormal. Yogyakarta: Pustaka Pelajar.

Hanum, L., Daengsari, D. P., dan Kemala, C. N. Penerapan Manajemen Stres Berkelompok Dalam Menurunkan Stres Pada Lanjut Usia Berpenyakit Kronis. Jurnal Psikologi, 2016; 43(1): 42-51.

Haruyama, S. The Miracle of Endorphin Sehat Mudah dan Praktis dengan Hormon Kebahagiaan. 2014. Bandung:Qanita.

Hidayat, A. A. (2019). Khazanah Terapi Komplementer Alternatif. Bandung: Penerbit Nuansa Cendekia.

Hill, N., \& Ritt, M. J. (2004). Keys to positive thinking. Jakarta: Bhuana Ilmu Populer.

Hussin, D. A., Samah, M. A. A., Suhaimi, A. A., \& Kamarudin, M. K. A. (2021). A study on knowledge, attitude and practice of COVID-19 pandemic among the residents. International Journal of Health Sciences, 5(2), 177 188. https://doi.org/10.29332/ijhs.v5n2.1378

Inabah, N. (2020). Hipnose Diri Sendiri.

Jansson-Fröjmark, M., \& Lindblom, K. (2008). A bidirectional relationship between anxiety and depression, and insomnia? A prospective study in the general population. Journal of psychosomatic research, 64(4), 443-449. https://doi.org/10.1016/j.jpsychores.2007.10.016

Joling, M., Vriend, C., Raijmakers, P. G., van der Zande, J. J., Lemstra, A. W., Berendse, H. W., ... \& van den Heuvel, O. A. (2019). Striatal DAT and extrastriatal SERT binding in early-stage Parkinson's disease and dementia with Lewy bodies, compared with healthy controls: An 123I-FP-CIT SPECT study. NeuroImage: Clinical, 22, 101755. https://doi.org/10.1016/j.nicl.2019.101755

Keliat, B. A. (2020). Dukungan kesehatan jiwa dan psikososial= Mental health and psychosocial support: covid-19: keperawatan jiwa.

Kistan, K., Malka, S., \& Musni, M. (2020). The relationship between knowledge, attitude, and readiness of academic community in Covid-19 spread prevention: Batari Toja Nursing Academy, Watampone. International Journal of Health \& Medical Sciences, 3(1), 72-78.

Kohen, D. P., \& Zajac, R. (2007). Self-hypnosis training for headaches in children and adolescents. The Journal of pediatrics, 150(6), 635-639. https://doi.org/10.1016/j.jpeds.2007.02.014

LaMontagne, L. L., Hepworth, J. T., \& Salisbury, M. H. (2001). Anxiety and postoperative pain in children who undergo major orthopedic surgery. Applied Nursing Research, 14(3), 119-124. https://doi.org/10.1053/apnr.2001.24410

Mahardika, I. M. R., Suyasa, I. G. P. D., Kamaryati, N. P., \& Wulandari, S. K. (2021). Health literacy is strongest determinant on self-monitoring blood glucose (SMBG) type 2 DM patients during COVID-19 pandemic at public health centre in Tabanan Regency. International Journal of Health \& Medical Sciences, 4(3), 288-297.

Maltezou, H. C., Katerelos, P., Poufta, S., Pavli, A., Maragos, A., \& Theodoridou, M. (2013). Attitudes toward mandatory occupational vaccinations and vaccination coverage against vaccine-preventable diseases of health care workers in primary health care centers. American journal of infection control, 41(1), 66-70. https://doi.org/10.1016/j.ajic.2012.01.028

McIntyre, H. D., Gibbons, K. S., Ma, R. C., Tam, W. H., Sacks, D. A., Lowe, J., ... \& Catalano, P. M. (2020). Testing for gestational diabetes during the COVID-19 pandemic. An evaluation of proposed protocols for the United Kingdom, Canada and Australia. diabetes research and clinical practice, 167, 108353. https://doi.org/10.1016/j.diabres.2020.108353

Murakami, Y., Tsumura, H., Sato, R., Fukuda, M., \& Kanda, H. (2017). Unhealthy mental states are positively associated with subjective pain or fatigue in specific body sites among high school teachers in Japan. Health, 9(9), 1313-1325.

Candra, I. W., Sumirta, I. N., \& Mustika, I. W. (2021). Effect of self-hypnosis therapy with positive self-talk on stress levels of COVID-19 mutual cooperation task force. International Journal of Health Sciences, 5(3), 441-448. 
Mustika, I. W., Kuswardhani, R. T., Suastika, K., Adiatmika, I. P. G., \& Iswara, N. P. A. A. P. (2021). Implementation of bali elderly care model to increase melatonin levels in elderly community. International Journal of Health Sciences, 5(2), 151-159. https://doi.org/10.29332/ijhs.v5n2.1362

Ortega-García, J. A., Ruiz-Marín, M., Cárceles-Álvarez, A., i López, F. C., \& Claudio, L. (2020). Social distancing at health care centers early in the pandemic helps to protect population from COVID-19. Environmental Research, 189, 109957. https://doi.org/10.1016/j.envres.2020.109957

Saltonstall, R. (1993). Healthy bodies, social bodies: men's and women's concepts and practices of health in everyday life. Social science \& medicine, 36(1), 7-14. https://doi.org/10.1016/0277-9536(93)90300-S

Sari, H. F., \& Murtini, M. (2015). Relaksasi untuk mengurangi stres pada penderita hipertensi esensial. Humanitas: Jurnal Psikologi Indonesia, 12(1), 12-28.

Spinhoven, P., Linssen, A. C. G., Van Dyck, R., \& Zitman, F. G. (1992). Autogenic training and self-hypnosis in the control of tension headache. General Hospital Psychiatry, 14(6), 408-415. https://doi.org/10.1016/01638343(92)90008-X

Widana, I.K., Sumetri, N.W., Sutapa, I.K., Suryasa, W. (2021). Anthropometric measures for better cardiovascular and musculoskeletal health. Computer Applications in Engineering Education, 29(3), 550561. https://doi.org/10.1002/cae.22202

Widjaja, G. (2021). Impact of human resource management on health workers during pandemics COVID-19: systematic review. International Journal of Health \& Medical Sciences, 4(1), 61-68.

\section{Biography of Authors}

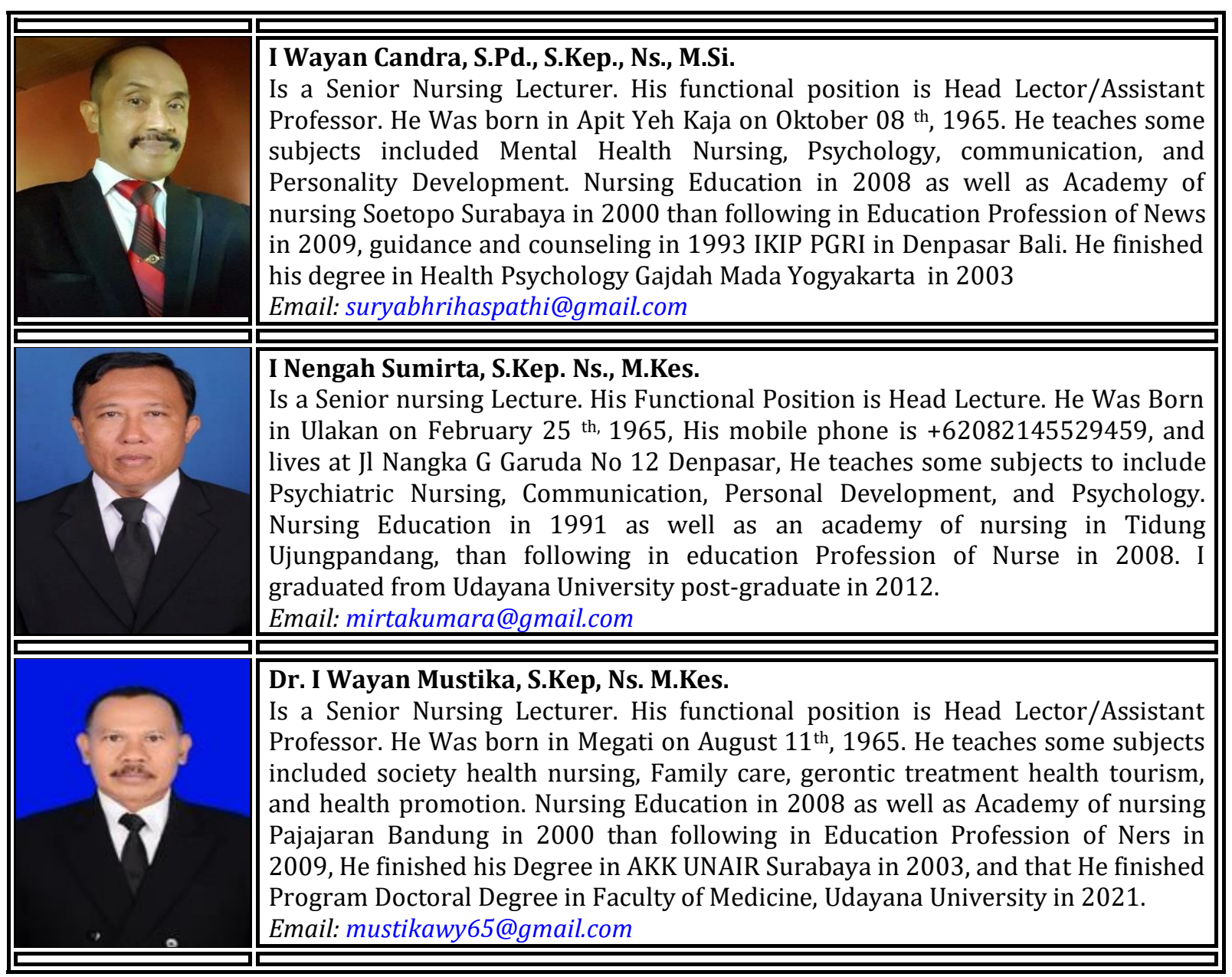

